\title{
Disinfection of leafy vegetables with activated waters
}

\author{
Teodora P. Popova* and Toshka E. Petrova \\ University of Forestry, Faculty of Veterinary Medicine, 10 Kl. Ohridski Blvd., Sofia 1756, Bulgaria \\ dr_tpopova@abv.bg
}

\begin{abstract}
The effect of ionized aqueous solutions (anolytes and catholytes) has been tested in lettuce treatment for decontamination and preservation of their freshness for a longer time. Anolytes and catholytes prepared without salt addition, as well as with $0.8 \% \mathrm{NaCl}$ and with a combination of $0.4 \% \mathrm{NaCl}$ and $0.4 \% \mathrm{Na}_{2} \mathrm{CO}_{3}$ were used. Opportunities to potentiate their action were also tested by adding $96 \%$ ethanol at a final concentration of $1 \%$.
\end{abstract}

It has been found that the three tested anolytes show the highest antimicrobial activity. This activity was maximal after potentiation by the addition of $96 \%$ ethanol at a final concentration of $1 \%$, and after 15 minutes no viable microorganisms were isolated from the leaves of the lettuce examined. The catholyte obtained by activation with $\mathrm{NaCl}$ also exhibited high antimicrobial activity. After storage for 2 weeks, the solutions retained to a large extent these properties and especially the anolyte obtained with $\mathrm{Na}_{2} \mathrm{CO}_{3}$.

The freshness of lettuce was kept for a longest time (10 days) after treatment for 15 minutes with salt-free anolyte, as well as with catholyte without salts. In the anolyte this property is retained after 14 days of storage, but in the catholyte it decreased somewhat after storage. The remaining lettuce, including the untreated controls and these treated with tap water, stayed fresh for 2 days, for the shortest time - the treated with an anolyte with $1 \% 96 \%$ ethanol.

Keywords: anolyte, catholyte, lettuce, decontamination, storage

\section{Introduction}

Leafy vegetables grow near the ground and from it, as well as from natural fertilizers, are contaminated with various microorganisms. Most of them are representatives of the epiphytic non pathogenic microflora, as well as soil bacilli, actinomycetes and fungi. In natural fertilization or application of irrigation water and sewage sludge, intestinal and other micro-organisms, some of which are pathogenic, may fall on plants. Outbreaks of gastrointestinal diseases after consumption of raw vegetables, including peeled, are evidence of this. In wet and warm storage of the vegetables, conditions are created for propagation of the microorganisms. Washing with water of the quality of the drinking water can reduce their microbial load. In many cases, however, good washing is not enough to prevent the risk of infecting consumers. Although there is a wide range of different agents for disinfecting fresh products, their efficacy is variable, and it is not possible to ensure the elimination of the pathogens. The range of microorganisms associated with fresh vegetables includes bacteria, viruses and parasites. Most of the reported outbreaks of infection, however, are associated with bacterial contamination, in particular with members of the family Enterobacteriaceae. From them, of particular importance are Salmonella enterica and Escherichia coli 0157 (Beuchat, 1996; European Commission, 2002).

In connection with the incidents that occurred in 2015 in the US and some European countries with diseases of customers of food chains caused by contaminated with pathogenic microorganisms fresh fruits and vegetables, consumed directly, pre-washing the vegetables in solutions of chemical, mainly chlorinecontaining disinfectants is entered in some eating sites (Ivanov, 2016). Chlorination has been widely applied by manufacturers, processors and traders of fresh fruit and vegetables worldwide for decades. These means, however, are not safe for consumers due to the residual amounts of the preparations used in the products processed. Chlorine can cause incomplete oxidation of organics substances and the formation of toxic side- 
compounds such as chloramines, chloroform and others, which in high doses have a carcinogenic effect (Rabin, 1986).

Although for the disinfection of fresh fruits and vegetables a wide variety of different agents are applied, none of them is able to completely eliminate the pathogens (Ivanov, 2016). In recent years, electrochemically activated aqueous solutions (EAAS) of sodium chloride have been reported to be broad spectrum and environmentally safe biocides (Gluhchev et al., 2018). Therefore, the aim of this study was to test the effect of the harmless to the macro-organism and the environment electrochemically activated aqueous solutions anolytes and catholytes for the desinfection of leafy vegetables and preservation of their freshness for a longer time.

\section{Materials ans Methods}

\section{Activated water solutions}

Anolytes. Activation time - $12 \mathrm{~min}$ - Anolyte prepared with $0.8 \% \mathrm{NaCl}$. Anolyte prepared with a combined solution of $0.4 \% \mathrm{NaCl}$ and $0.4 \% \mathrm{Na}_{2} \mathrm{CO}_{3}$. Anolyte of $0.8 \% \mathrm{NaCl}$ potentiated by adding $96 \%$ ethanol to a final concentration of $1 \%$. Anolyte of a combination of $0.4 \% \mathrm{NaCl}$ and $0.4 \% \mathrm{Na}_{2} \mathrm{CO}_{3}$ potentiated by addition of $96 \%$ ethanol at a final concentration of $1 \%$. Anolyte prepared without salts addition.

Catholytes. Activation time - $12 \mathrm{~min}$ : Catholyte prepared with $0.8 \% \mathrm{NaCl}$. Catholyte prepared with a combined solution of $0.4 \% \mathrm{NaCl}$ and $0.4 \% \mathrm{Na}_{2} \mathrm{CO}_{3}$. Catholyte prepared without salts addition.

Nutritient media. Seedings for isolating microorganisms were made on Mueller-Hinton agar (BULBIO NCIPD Ltd. - Sofia, Bulgaria).

Plant material. Fresh lettuces purchased from commercial outlets on the day of experiments were used.

\section{Experimental designs}

By 3 lettuce leaves were placed in the following EAAS: 1) Anolyte with $0,8 \% \mathrm{NaCl} ; 1^{\prime}$ ) Anolyte prepared without salts addition; 2) Anolyte with combination of $0,4 \% \mathrm{NaCl}$ and $\left.0,4 \% \mathrm{Na}_{2} \mathrm{CO}_{3} ; 3\right) 1 \% 96^{\circ}$ ethanol added to the anolyte with $0,8 \% \mathrm{NaCl}$; 4) $1 \% 96^{\circ}$ ethanol added to the anolyte with combination of $0,4 \% \mathrm{NaCl}$ and $0,4 \%$ $\left.\mathrm{Na}_{2} \mathrm{CO}_{3} ; 5\right)$ Catholyte with $0,8 \% \mathrm{NaCl} ; 5^{\prime}$ ) Catholyte prepared without salts addition; 6) Tap water; 7) Catholyte with combination of $0,4 \% \mathrm{NaCl}$ and $0,4 \% \mathrm{Na}_{2} \mathrm{CO}_{3} ; \mathrm{K}$ ) Untreated control.

After 15 minutes imprint seedings from each leaf were made in a particular sector of size $1 / 3$ of a $20 \mathrm{~cm}^{2}$ Mueller Hinton agar plate. After incubation under aerobic conditions at $37^{\circ} \mathrm{C}$ for 24 hours the formed colonies were counted and presented as colonies forming units on $\mathrm{cm} 2\left(\mathrm{CFU} / \mathrm{cm}^{2}\right)$ from the surface of the leafy vegetables studied. Lettuces were kept at room temperature for 10 days and a daily assessment of their freshness was made to assess the effect of treatment on this indicator as well.

The EAASs used were stored for 14 days at room temperature in the dark and the experiments were repeated to assess to what extent they retained their activity.

Each experiment was performed in triplicate with by three plants..

Statistical analysis. The data were statistically processed, and the results are presented as an arithmetic mean value \pm standard deviation. Differences between two mean values were evaluated for statistical significance with Student's t-test, beeing statistically reliable at $P<0.05$ and with high statistical significance at $P<0.01$ and $\mathrm{P}<0.001$.

\section{Results}


The physical indicators $\mathrm{pH}$, Oxidation Reduction Potential (ORP) and temperature of the EAAS tested are presented in Tables 1 and 2.

Table 1. Physical indicators of the studied anolytes

\begin{tabular}{|l|l|l|l|l|}
\hline \multicolumn{2}{|l|}{ Starting composition } & $\mathbf{p H}$ & $\mathbf{O R P}, \mathbf{~ m V}$ & $\mathbf{t}{ }^{\circ} \mathbf{C}$ \\
\hline \multirow{4}{*}{$\begin{array}{l}\text { Aqueous sodium } \\
\text { chloride solution 0.8\% }\end{array}$} & before electrolysis & 8,92 & $218 \mathrm{mV}$ & 22,1 \\
\cline { 2 - 5 } & first day & 2,47 & $1000 \mathrm{mV}$ & 20,7 \\
\cline { 2 - 5 } & after 7 days & 2,55 & 263 & 22,0 \\
\cline { 2 - 5 } & after 14 days & 2,51 & 266 & 21,2 \\
\hline $\begin{array}{l}\text { Aqueous solution of } \\
\text { sodium chloride (0.4\%) } \\
\text { and sodium carbonate } \\
\text { (0.4\%) }\end{array}$ & before electrolysis & 11,33 & $109 \mathrm{mV}$ & 18,5 \\
\cline { 2 - 5 } & first day & 10,74 & $439 \mathrm{mV}$ & 20,6 \\
\cline { 2 - 5 } & after 7 days & 10,36 & -200 & 21,5 \\
\cline { 2 - 5 } & after 14 days & 10,32 & -196 & 20,9 \\
\hline \multirow{4}{*}{ Water without salts } & before electrolysis & 9,57 & $302 \mathrm{mV}$ & 18,7 \\
\cline { 2 - 5 } & first day & 3,55 & $743 \mathrm{mV}$ & 22,5 \\
\cline { 2 - 5 } & after 7 days & 3,47 & 207 & 25 \\
\cline { 2 - 5 } & after 14 days & 3,35 & 205 & 20,8 \\
\hline
\end{tabular}

ORP - oxidation-reduction potential

Table 2. The physical indicators of the examined catholytes

\begin{tabular}{|c|c|c|c|c|}
\hline \multicolumn{2}{|l|}{ Starting composition } & \multirow{2}{*}{$\begin{array}{l}\mathbf{p H} \\
8,92\end{array}$} & \multirow{2}{*}{$\begin{array}{l}\text { ORP, mV } \\
218 \mathrm{mV}\end{array}$} & \multirow{2}{*}{$\begin{array}{l}\mathbf{t}^{\circ} \mathbf{C} \\
22,1\end{array}$} \\
\hline Aqueous & before electrolysis & & & \\
\hline & first day & 11,91 & $-768 m V$ & 20,7 \\
\hline & after 7 days & 11,52 & -266 & 21,8 \\
\hline & after 14 days & 11,43 & -259 & 20,6 \\
\hline \multirow{4}{*}{ 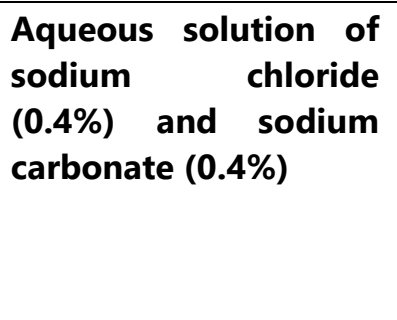 } & before electrolysis & 11,33 & $109 \mathrm{mV}$ & 18,5 \\
\hline & first day & 11,95 & $-723 \mathrm{mV}$ & 19,7 \\
\hline & after 7 days & 11,31 & -256 & 21,7 \\
\hline & after 14 days & 11,18 & -246 & 21,3 \\
\hline
\end{tabular}




\begin{tabular}{|l|l|l|l|l|}
\hline \multirow{4}{*}{ Water without salts } & before electrolysis & 9,57 & $302 \mathrm{mV}$ & 18,7 \\
\cline { 2 - 5 } & first day & 10,03 & $-214 \mathrm{mV}$ & 22,5 \\
\cline { 2 - 5 } & after 7 days & 8,47 & -89 & 21,8 \\
\cline { 2 - 5 } & after 14 days & 8,23 & -70 & 20,7 \\
\hline
\end{tabular}

\section{ORP - oxidation-reduction potential}

The highest ORP immediately after preparation was recorded in the anolyte obtained with $0.8 \% \mathrm{NaCl}(1000$ $\mathrm{mV}$ ), followed by the salt-free anolyte $(743 \mathrm{mV})$ and that of $\mathrm{NaCl}$ and $\mathrm{Na}_{2} \mathrm{CO}_{3}(439 \mathrm{mV})$, as shown in Table 1. In the catholytes (Table 2), the lowest ORP was recorded in that obtained with $0.8 \% \mathrm{NaCl}(-768 \mathrm{mV})$, followed by catholyte with $\mathrm{NaCl}$ and $\mathrm{Na}_{2} \mathrm{CO}_{3}(-723 \mathrm{mV})$ and the salts-free one $(-214 \mathrm{mV})$. The $\mathrm{pH}$ value was lowest for the anolyte with $\mathrm{NaCl}$ (2.47), and the highest for the catholyte with $\mathrm{NaCl}$ and $\mathrm{Na}_{2} \mathrm{CO}_{3}$ (11.95), very similar to that with $\mathrm{NaCl}$ (11.91). As can be seen from Tables 1 and 2, ORP of the investigated solutions decreased more significantly in the first week after preparation and much less in the second week. Changing the $\mathrm{pH}$ of the solutions over the two-week study period was to a much lesser extent.

The results of the microbiological studies for the amount of microorganisms isolated from lettuce after 15 minutes of treatment with different EAAS reported after 24 hours incubation of the seedings at $37^{\circ} \mathrm{C}$ are presented in Table 3 and Figures 1 and 2.

Table 3. Amount of microorganisms after $15 \mathrm{~min}$ action of the electrochemically activated aqueous solutions (fresh and stored for 14 days) on lettuces presented in $\mathrm{CFU} / \mathrm{cm}^{2}$ of their surface

\begin{tabular}{|c|c|c|c|}
\hline \multirow{2}{*}{$\begin{array}{l}\text { Sampl } \\
\text { e№ }\end{array}$} & \multirow[t]{2}{*}{ Type of activated solution } & \multicolumn{2}{|c|}{ Quantity of microorganisms (CFU/ $\mathrm{cm}^{2}$ ) } \\
\hline & & fresh & stored 14 days \\
\hline 1 & anolyte of $\mathrm{NaCl}$ & $0,23^{\star} \pm 0,085^{\star \star}$ & $3,23 \pm 1,605$ \\
\hline $1^{\prime}$ & salts-free anolyte & $0,065 \pm 0,09$ & $3,25 \pm 0,54$ \\
\hline 2 & anolyte of $\mathrm{Na}_{2} \mathrm{CO}_{3}$ & $1,665 \pm 0,625$ & $1,135 \pm 0,26$ \\
\hline 3 & $1 \% 96^{\circ}$ ethanol in anolyte of $\mathrm{NaCl}$ & 0 & $2,835 \pm 0,69$ \\
\hline 4 & $1 \% 96^{\circ}$ ethanol in anolyte of $\mathrm{Na}_{2} \mathrm{CO}_{3}$ & 0 & 0 \\
\hline 5 & catholyte of $\mathrm{NaCl}$ & $20,2 \pm 0,695$ & $5,95 \pm 0,31$ \\
\hline $5^{\prime}$ & salts-free catholyte & $40,665 \pm 1,445$ & $10,435 \pm 2,205$ \\
\hline 6 & tap water & $44,065 \pm 3,74$ & $10,68 \pm 1,96$ \\
\hline 7 & catholyte of $\mathrm{Na}_{2} \mathrm{CO}_{3}$ & $51,525 \pm 2,695$ & - \\
\hline $\mathbf{k}$ & untreated control & $56,015 \pm 3,77$ & $10,835 \pm 2,29$ \\
\hline
\end{tabular}

${ }^{*}$ Average. ** Standard deviation. 
As can be seen from the summarized data, the three anolytes tested showed the highest antimicrobial activity. This activity was maximal after potentiation by adding $96 \%$ ethanol to a final concentration of $1 \%$. After treatment with freshly prepared anolytes with added ethanol for 15 minutes, viable microorganisms from the leaves of the lettuces tested were not isolated. The catholyte obtained by activation with $\mathrm{NaCl}$ also exhibited high antimicrobial activity. In the fresh solutions differences in antimicrobial activity were statistically significant between samples 1 and $6(P<0.001) ; 1$ and $2(P<0.001) ; 1^{\prime}$ and $2(P<0.001)$; between 2 and $4(P$ $<0.05)$; between 1 and $3(P<0.05)$; between 5 and $6(P<0.01)$ and between 6 and $k(P<0.05)$. The differences were not significant between 1 and $1^{\prime}(P>0.05)$; between $5^{\prime}$ and $6(P>0.05)$; between 7 and $k(P>0.05)$. The catholyte prepared without salts and the catholyte with $\mathrm{Na}_{2} \mathrm{CO}_{3}$ did not exhibit significant antimicrobial activity. The treatment only with water resuled in a minor reduction in microbial contamination.

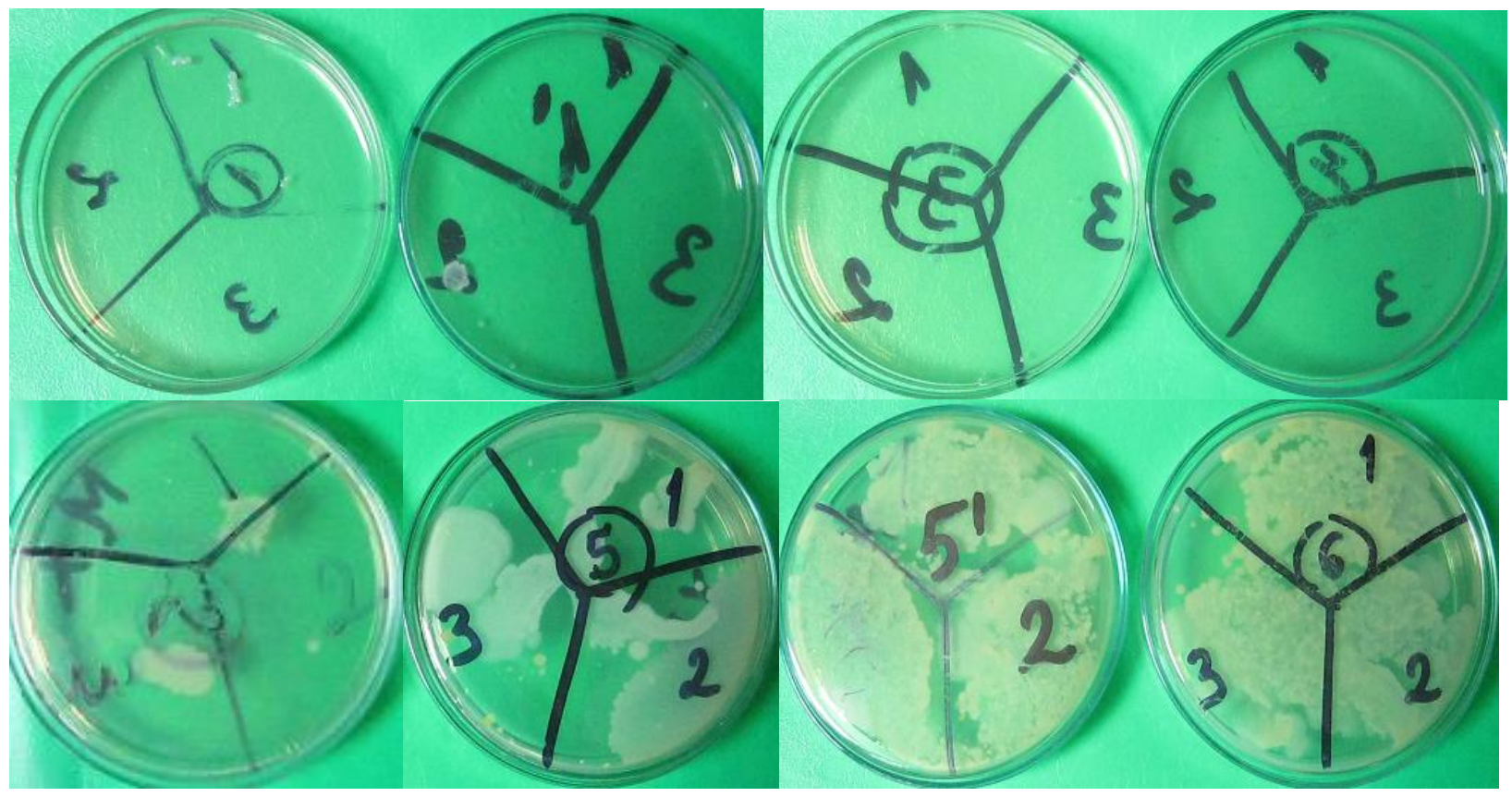

Figure 1. Growth of microorganisms on Mueller Hinton agar after imprint seedings of the treated with freshly prepared EAASs lettuces. From left to right, after treatment with: 1) Anolyte with $\mathrm{NaCl}$; 1') Anolyte without salts; 3) Anolyte with $\mathrm{NaCl}$ and $1 \%$ of $96 \%$ ethanol; 4) Anolyte with $\mathrm{Na}_{2} \mathrm{CO}_{3}$ and $1 \%$ of $96 \%$ ethanol; below: 2) Anolyte with $\mathrm{Na}_{2} \mathrm{CO}_{3} ; 5$ ) Catholyte with $\mathrm{NaCl} ; 5$ ) Catholyte without salts; 6) Tap water.

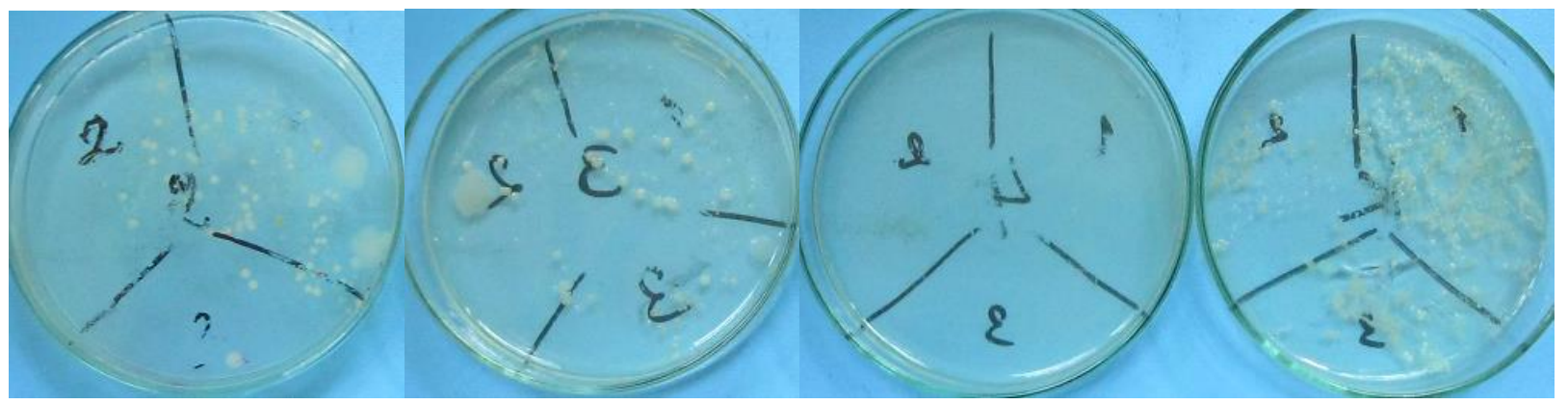

Figure 2. Growth of microorganisms on Mueller Hinton agar after imprint seedings of the some of lettuces treated with stored 14 days EAASs. From left to right, after treatment with: 2) Anolyte with $\mathrm{Na}_{2} \mathrm{CO}_{3} ; 3$ ) Anolyte with $\mathrm{NaCl}$ and $1 \%$ of $96^{\circ}$ ethanol; 4) Anolyte with $\mathrm{Na}_{2} \mathrm{CO}_{3}$ and $1 \%$ of $96^{\circ}$ ethanol; $\mathrm{k}$ ) untreated control. 
Table 4. Lettuces freshness within 10 days after treatment with freshly prepared EAASs presented as $\%$ of the initial state

\begin{tabular}{|c|c|c|c|c|c|}
\hline \multirow{2}{*}{$\begin{array}{l}\text { Sample } \\
\text { № }\end{array}$} & \multirow[b]{2}{*}{ Type of activated solution } & \multicolumn{4}{|c|}{ Freshness } \\
\hline & & $1^{\text {st }}$ day & $2^{\text {nd }}$ day & $7^{\text {th }}$ day & $10^{\text {th }}$ day \\
\hline 1 & anolyte of $\mathrm{NaCl}$ & - & - & - & - \\
\hline $\mathbf{1}^{\prime}$ & salts-free anolyte & $100 \%$ & $100 \%$ & $100 \%$ & $90 \%$ \\
\hline 2 & anolyte of $\mathrm{Na}_{2} \mathrm{CO}_{3}$ & $90 \%$ & $70 \%$ & - & - \\
\hline 3 & $1 \% 96^{\circ}$ ethanol in anolyte of $\mathrm{NaCl}$ & $50 \%$ & - & - & - \\
\hline 4 & $1 \% 96^{\circ}$ ethanol in anolyte of $\mathrm{Na}_{2} \mathrm{CO}_{3}$ & $70 \%$ & - & - & - \\
\hline 5 & catholyte of $\mathrm{NaCl}$ & $90 \%$ & $70 \%$ & - & - \\
\hline $5^{\prime}$ & salts-free catholyte & $100 \%$ & $100 \%$ & $100 \%$ & $90 \%$ \\
\hline 6 & tap water & $90 \%$ & $70 \%$ & - & - \\
\hline 7 & catholyte of $\mathrm{Na}_{2} \mathrm{CO}_{3} ;$ & $80 \%$ & - & - & - \\
\hline $\mathbf{k}$ & untreated control & $90 \%$ & $70 \%$ & - & - \\
\hline
\end{tabular}

After storage for 2 weeks, the solutions retained to a large extent these properties and especially the anolyte obtained with $\mathrm{Na}_{2} \mathrm{CO}_{3}$. The antimicrobial activity of the catholyte obtained with $\mathrm{NaCl}$ was also maximally preserved. The differences are statistically significant between samples 5 and $6(P<0.05)$; as well as the differences of samples $1,1^{\prime}, 2,3$ and 4 with the untreated control $(P<0.05)$, but not of samples 5, 5', and 6 with the untreated control $(P>0.05)$. The differences were not statistically significant between samples $1,1{ }^{\prime}$ and 2 ( $P$ $>0.05)$; between 1 and $3(P>0.05)$; between 2 and $4(P>0.05)$ and between 5 and $5^{\prime}(P>0.05)$.

The duration of preservation of freshness of the leafy vegetables studied after treatment with freshly prepared and stored for two weeks EAASs can be seen in Tables 4 and 5 as well as Figures 3, 4 and 5 .

Table 5. Lettuces freshness up to 10 days after treatment with EAASs, stored for 2 weeks, expressed as \% of the initial state

\begin{tabular}{|l|l|l|l|l|l|}
\hline \multirow{2}{*}{$\begin{array}{l}\text { Sample } \\
\text { No }\end{array}$} & \multirow{4}{|l|}{ Freshness } \\
\cline { 3 - 6 } & Type of activated solution & $\mathbf{1}^{\text {st }}$ day & $\mathbf{2}^{\text {nd }}$ day & $\mathbf{7}^{\text {th }}$ day & $\mathbf{1 0}^{\text {th }}$ day \\
\hline $\mathbf{1}$ & anolyte of $\mathrm{NaCl}$ & $90 \%$ & $80 \%$ & - & - \\
\hline $\mathbf{1}^{\prime}$ & salts-free anolyte & $100 \%$ & $100 \%$ & $100 \%$ & $90 \%$ \\
\hline $\mathbf{2}$ & anolyte of $\mathrm{Na}_{2} \mathrm{CO}_{3}$ & $90 \%$ & $80 \%$ & - & - \\
\hline
\end{tabular}




\begin{tabular}{|l|l|l|l|l|l|}
\hline $\mathbf{3}$ & $1 \% 96^{\circ}$ ethanol in anolyte of $\mathrm{NaCl}$ & $90 \%$ & $90 \%$ & - & - \\
\hline $\mathbf{4}$ & $1 \% 96^{\circ}$ ethanol in anolyte of $\mathrm{Na}_{2} \mathrm{CO}_{3}$ & $90 \%$ & $80 \%$ & - & - \\
\hline $\mathbf{5}$ & catholyte of $\mathrm{NaCl}$ & $90 \%$ & $80 \%$ & - & - \\
\hline $\mathbf{5}^{\prime}$ & salts-free catholyte & $100 \%$ & $100 \%$ & - & - \\
\hline $\mathbf{6}$ & tap water & $90 \%$ & $80 \%$ & - & - \\
\hline $\mathbf{k}$ & untreated control & $90 \%$ & $80 \%$ & - & - \\
\hline
\end{tabular}

From the figures and the tables, it can be seen, that freshness was kept for the longest time in the lettuces treated for 15 minutes with anolyte obtained without addition of salts ( $\left.1^{\prime}\right)$ and with saltless catholyte $\left(5^{\prime}\right)$. These leafy vegetables remain fresh 10 days after the treatment. In the anolyte this property is retained after 14 days of storage, but in the the catholite it decreased somewhat after the storage. The remaining lettuce, including untreated controls and the treated with tap water, remain fresh for 2 days but no longer. It is also seen that the addition of $1 \%$ of $96 \%$ ethanol to the anolyte does not contribute to longer storage of the plant's freshness, but on the contrary, their freshness after 24 hours is reduced in comparison with the unthreated controls. After treatment with freshly prepared anolyte with $\mathrm{NaCl}$ they were preserved for the shortest time and still at the 24th hour they were withered.

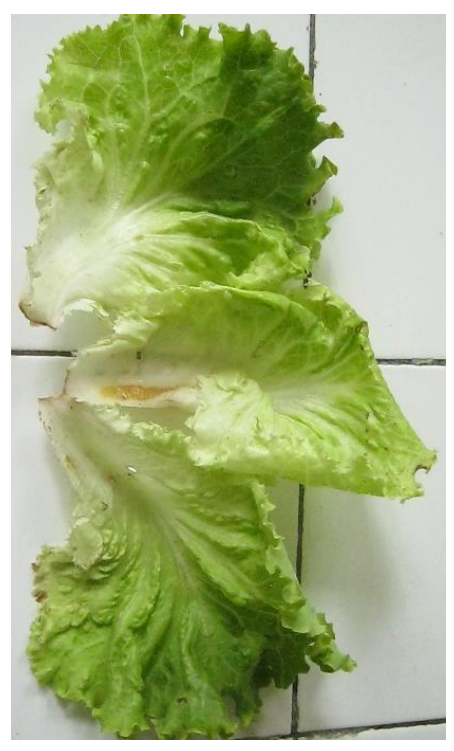

K

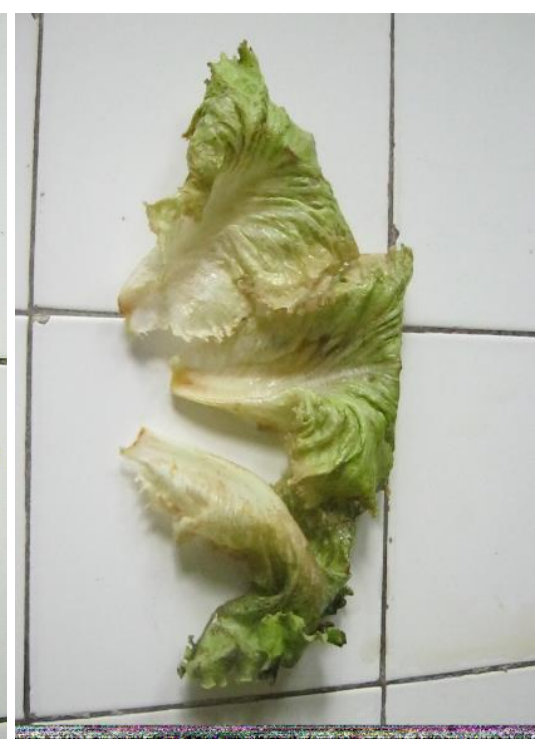

1

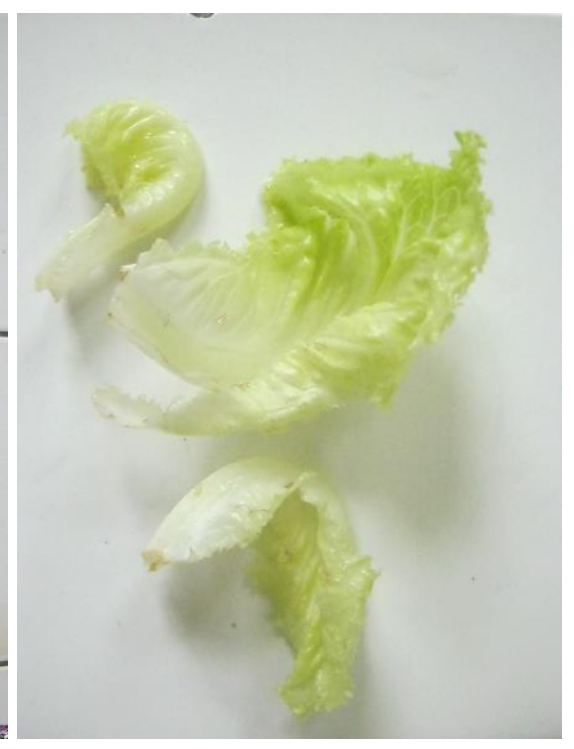

$1^{\prime}$ 


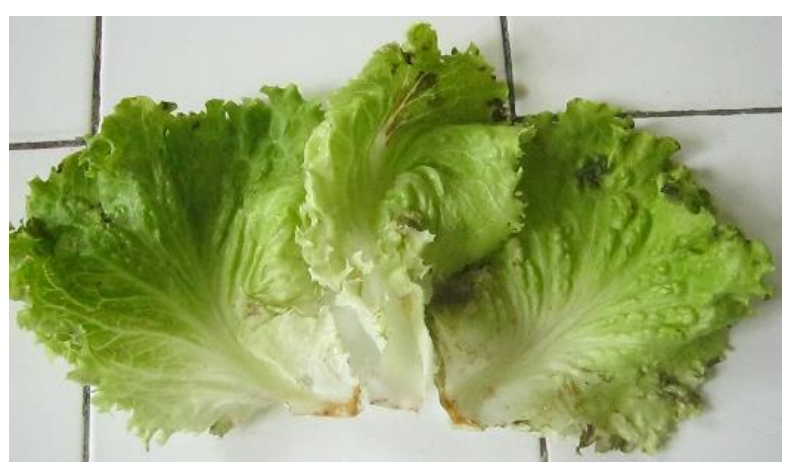

2

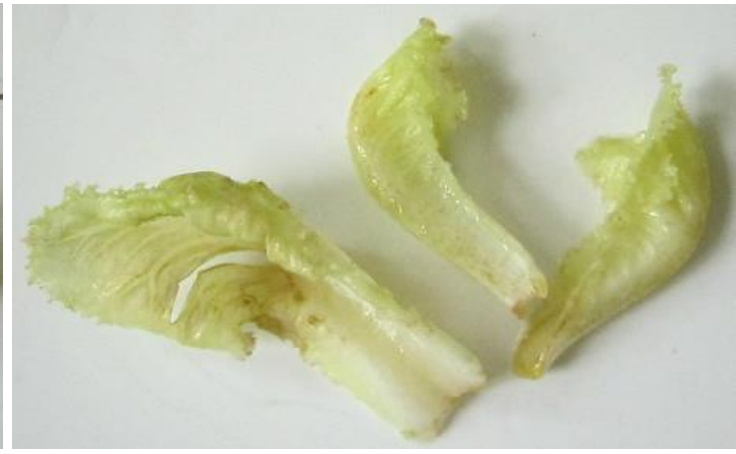

3

Figure 3. Lettuces freshness 24 hours after treatment with freshly prepared EAASs: k) Untreated control; 1) Anolyte with $\mathrm{NaCl} ; 1$ ') Anolyte without salts; 2) Anolyte with $\mathrm{Na}_{2} \mathrm{CO}_{3} ; 3$ ) Anolyte with $\mathrm{NaCl}$ and $1 \%$ of $96 \%$ ethanol.

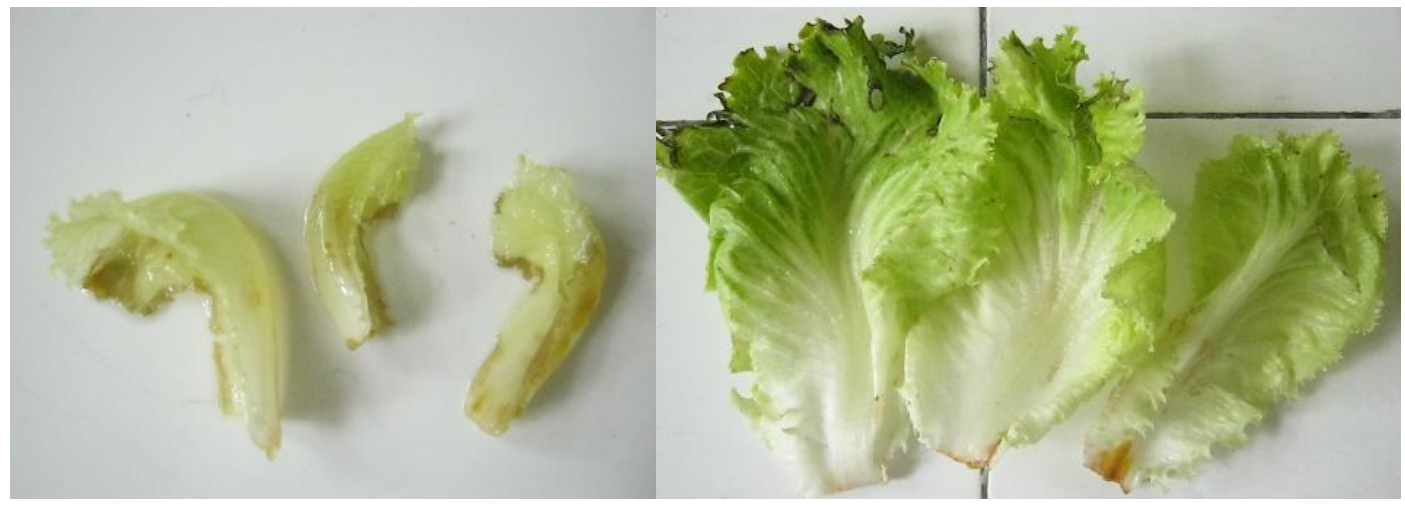

4

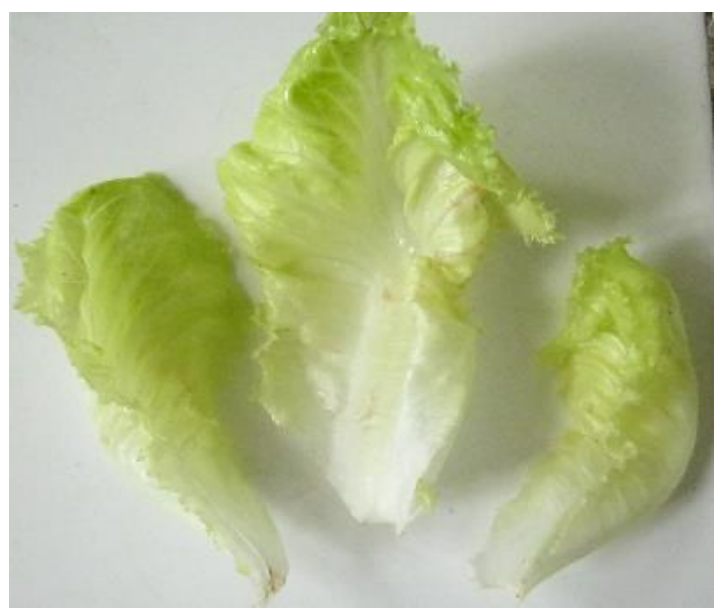

$5^{\prime}$
5

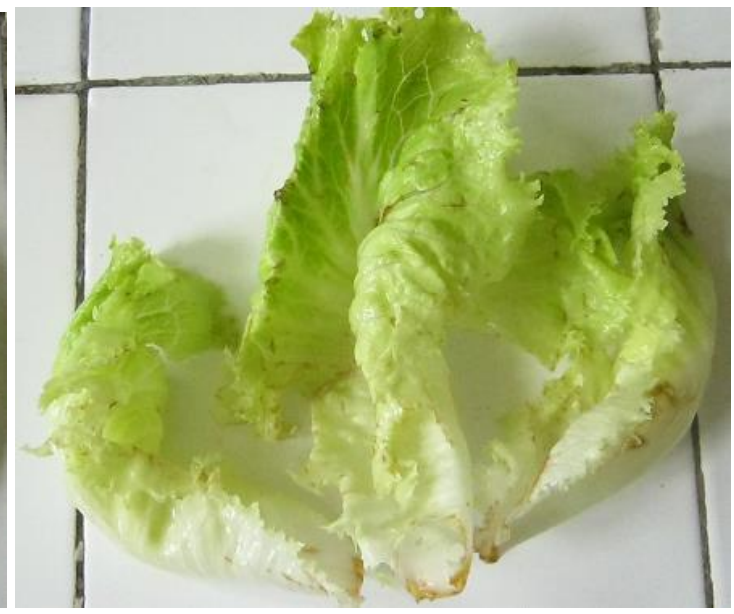

6

Figure 4. Lettuces freshness 24 hours after treatment with freshly prepared EAASs: 4) Anolyte with $\mathrm{Na}_{2} \mathrm{CO}_{3}$ and $1 \%$ of $96 \%$ ethanol; 5) Catholyte with $\mathrm{NaCl}$; $5^{\prime}$ ) Catholyte without salts; 6) Tap water. 


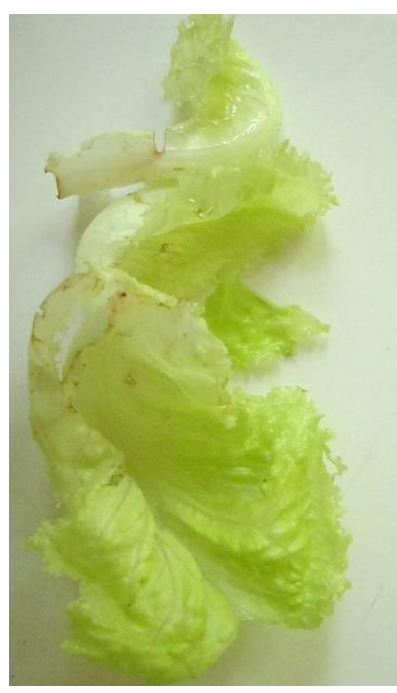

1

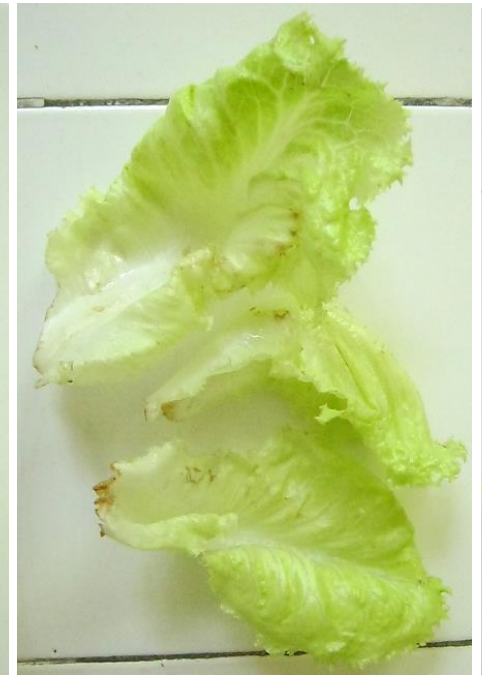

$5^{\prime}$

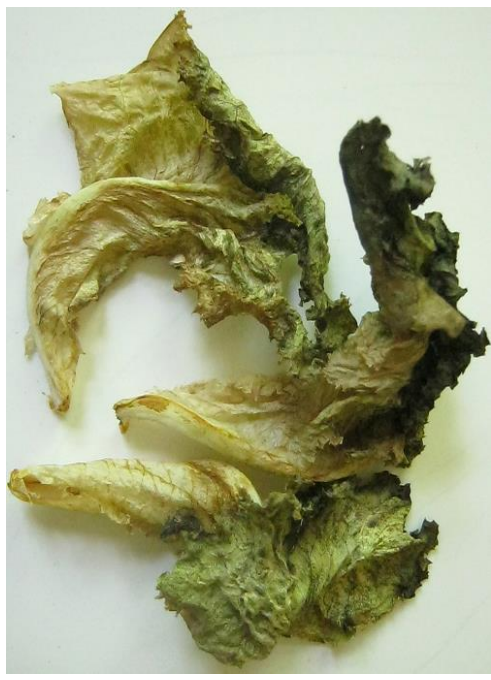

$\mathbf{K}$

Figure 5. Freshness of some of the lettuces 1 week after treatment with freshly prepared EAASs - left to right: 1') Anolyte without salts; 5') Catholyte without salts; (k) Untreated control.

\section{Discussion}

Although washing with water contributes to reducing the microbial contamination of raw vegetables, it is far from sufficient to decontaminate them prior to direct consumption. This is clearly evident from the results of the current studies that are in accordance with those of other authors. In 1998, Beuchat reported that the effect of washing in terms of reducing the number of bacteria on the surface of fresh fruit and vegetables was negligible - of the order of 0.1 to $1 \log ^{10} \mathrm{CFU}$. For this reason, additional processing is required.

In Bulgaria, Ivanov (2016) first noted the possibility of using electrochemically activated aqueous sodium chloride solutions for the safe disinfection of fresh vegetables intended for direct consumption but without giving any concrete results in this regard. There are data, that these solutions are broad-spectrum and environmentally safe biocidal products. During electrolysis in the process of their preparation, activated substances with biocidal properties and with antimicrobial action against a wide range of microorganisms are formed. They are safe for humans, animals and the environment. The active substances are chlorineoxygenous and peroxide compounds, which relatively quickly change their concentration (Ignatov et al., 2015; Gluhchev et al., 2018). No resilience can be built against EAASs by the microorganisms, as these solutions have a constantly changing dynamic composition which is dependent on the salts used. The broad spectrum antimicrobial activity of the EAASs was proven by studies by a number of authors. Gurgulova et al. (2010, 2011), Popova et al. (2016 a, c) and others found high activity of such solutions against Gram-negative and Gram-positive bacteria, including spore-forming species. Tasheva et al. (2010) reported for the antimycotic effect of EAASs, and for their antiviral activity - Atanasov et al. (2014), Karadzhov et al. (2015) and others. The antimicrobial activity of such solutions is realized even in high protein content environment such as water from lagoons for the storage of bovine manure (Peev, 2017) and bioshlame (Dimitrova et al., 2013).

The antimicrobial activity of EAASs directly depends on their oxidation-reduction potential, as it manifests itself only in its certain range. It is characteristic of them that their properties change depending on their ORP. According to the studies of Gluhchev et al. (2018) characteristic of the anolyte and the catholyte is that the former possesses reduced electron activity and has pronounced oxidizing properties, and the second has increased electron activity and exhibits regenerator properties. The results obtained by us are consistent with those of Dimitrova et al. (2013), according to which solutions with the highest ORP inhibit the the total number of bacterial cells to the greatest extent, as this is explained by the high ORP and oxidative stress on cellular membrane structures, as a result of which they are damaged. 
Our research strongly point out, that EAASs, activated with $\mathrm{NaCl}$, as well as with the participation of $\mathrm{Na}_{2} \mathrm{CO}_{3}$, can be used with great success for the desinfection of leafy vegetables. This disinfection is efficient, safe and is combined with an extension of the period of preservation of their freshness. The antimicrobial activity of these EAASs can be potentiated by adding $96 \%$ ethanol to a final concentration of $1 \%$. Thus, complete destruction of microorganisms on the surface of vegetables is achieved, but they must be consumed within 24 hours. The anolyte, obtained without the addition of salts, along with the decontamination of these vegetables, ensures keeping their freshness for more than a week. After storage for 2 weeks, solutions retained to a great extent these properties. This is consistent with the results of our previous studies demonstrating that the antimicrobial activity of these solutions is maintained even after storage for weeks at room temperature (Popova et al., 2016 b). Obviously, besides the ORP, an important role for the antimicrobial activity of the solutions we tested has and their $\mathrm{pH}$, which changes very little during the two-week study period. The data from our studies show that the change in ORP of the tested solutions, which is essential for their antimicrobial activity, is greatest in the first week after their production and much less in the second one. The anolytes and especially this with $\mathrm{Na}_{2} \mathrm{CO}_{3}$, turn out a sure means of safe decontamination of leafy vegetables even when the solutions have been stored for two weeks.

\section{Conclusion}

The three tested anolytes obtained upon activation with $0.8 \% \mathrm{NaCl}$; with a combination of $0.4 \% \mathrm{NaCl}$ and $0.4 \%$ $\mathrm{Na}_{2} \mathrm{CO}_{3}$ as well as without salt addition, showed the highest antimicrobial activity on the lettuce microflora. The catholyte produced by activation with $0.8 \% \mathrm{NaCl}$ also exhibited high antimicrobial activity. The potentiation of the anolyte by addition of $96 \%$ ethanol to a final concentration of $1 \%$ further increased this antimicrobial activity and after 15 minutes no viable microorganisms were isolated from the leaves of the lettuces examined. The electrochemically activated aqueous solutions largely retained these properties after storage for 2 weeks and especially the anolyte prepared with $\mathrm{Na}_{2} \mathrm{CO}_{3}$. The lettuce freshness was retained for a longest time (10 days) after treatment for 15 minutes with salts-free anolyte, as well as with catholyte without salts. In the anolyte this property was retained after 14 days of storage, but in the catholyte it decreased to a certain degree during the storage. Addition of $96 \%$ ethanol to a final concentration of $1 \%$ to the anolyte provided complete decontamination of the lettuce, but did not contribute to longer storage of the plants' freshness, but on the contrary they withered after 24 hours.

\section{Acknowledgement}

This research was funded by the University of Forestry - Sofia with funds allocated of the State Budget as a result of implementation of Contract No B25 / 07.03 .2018 for a scientific project on "Testing antimicrobial activity of an electrochemically activated aqueous solution anolyte".

\section{References}

1. Atanasov, A, Karadzhov S, Ivanova E., Mosin O., Ignatov I.. 2014. Study of the Effects of Electrochemical Aqueous Sodium Chloride Solution (Anolyte) on the Virus of Classical Swine Fever Virus. Mathematical Models of Anolyte and Catolyte as Types of Water. Journal of Medicine, Physiology and Biophysics 4: 1-26. www.iiste.org.

2. Beuchat, L. R. 1996. Pathogenic microorganisms associated with fresh produce. J. Food Prot. 59: 204216.

3. Beuchat, L. R. 1998. Surface decontamination of fruits and vegetables eaten raw: a review. World Health Organization (WHO/FSF/FOS/98.2).

4. Dimitrova, L., Kassovski V., Tzvetkova I., Hubenov V., Mihailova C., Simeonov I., Ivanov N., Gluhchev G., Naidenski H. 2013. Bactericidal effect of electrochemically activated water on the aerobic bacterial population of biosylams. BAS, Project No DFNI-E02/2013, Research Fund, Bulgaria. 
5. European Commission. Risk Profile on the Microbiological Contamination of Fruits and Vegetables Eaten Raw. Report of the Scientific Committee on Food. Health \& Consumer Protection DirectorateGeneral Directorate C - Scientific Opinions C2 - Management of scientific committees II; Scientific cooperation and networks. Scientific Committee on Food SCF/CS/FMH/SURF/Final, 29 April 2002.

6. Gluhchev, G, Mehandjiev D, Ignatov I, Karadzhov S, Pesheva Y, Atanasov A. 2018. Water electrolysis processes in catholyte and anolyte results with differential non - equilibrium water spectrum. European Journal of Medicine 6, 1: 3 - 12. ISSN: 2310-3434. DOI: 10.13187/ejm.2018.1.3.

7. Gurgulova, K, Georgieva T, Karadzhov S, Yordanov I, Atanasov G. 2010. Biocidal action of electrochemically activated solutions (anolytes) against microorganisms responsible for rotten diseases in bee brood. NVS, Contract № 6 / 07.07.2010.

8. Gurgulova, K., Karadzhov S., Gogov Y., Georgieva T., Yordanov I. 2011. "Application in veterinary medicine of anolytes obtained by electrochemical activation of aqueous solutions of alkali and alkaline earth salts". Agricultural Academy, Anim Breeding Sci. XLVIII, 1/2011.

9. Ignatov, I., Gluhchev G., Karadzhov S., Miloshev G., Ivanov N., Mosin O. 2015. Preparation of Electrochemically Activated Water Solutions (Catholyte/Anolyte) and Studying Their Physical-Chemical Properties. Journal of Medicine, Physiology and Biophysics 11: 1-21. www.iiste.org, ISSN 2422-8427 (Online).

10. Ivanov, Y. 2016. Types of chemical compounds that can be used for disinfection of vegetables intended for direct consumption, ways of use, permissible levels of residues after a subsequent washing with drinking water from the point of view of the safety of the offered final product.Bulgarian Agency of Food Safety, Center for Risk Assessment, Standpoint No 0147-0687 of 31.08.2016.

11. Karadzhov, S., Atanasov A., Ivanova E., Mosin O., Ignatov I. 2014. Mathematical Models of Electrochemical Aqueous Sodium Chloride Solutions (Anolyte and Catholyte) as Types of Water. Study of the Effects of Anolyte on the Virus of Classical Swine Fever Virus. Journal of Health, Medicine and Nursing An Open Access Journal 5: 30-55. www.iiste.org.

12. Peev, B. 2017. Study of the possibilities for accelerated composting of bovine manure. Dissertation work for awarding the educational and scientific degree "Doctor", Bulgarian Food Safety Agency, NDRVMI, Sofia, pp. 144-165.

13. Popova, T. P., Petrova T., Karadzhov S. 2016 a. Investigation of the biocidal effect of electrochemically activated aqueous sodium shloride solution on Gram-negative pathogenic bacteria. Int..J. Curr. Microbiol. App. Sci. 5, 1: 624-632, (DOI: http://dx.doi.org/10.20546/ijcmas.2016.501.063

14. Popova, T. P., Petrova T., Karadzhov S. 2016. Investigation of the Action of the Anolyte after Different Storage Times on the Gram-negative Bacteria. Int.J.Curr.Microbiol.App.Sci. 5, 9: 530-539, 2016 b. doi: http://dx.doi.org/10.20546/ijcmas...509.059.

15. Popova, T. P., Petrova T., Karadzhov S., Krustanova G. 2016 c. Investigation of the biocidal effect of electrochemically activated aqueous sodium chloride solution on Staphylococcus aureus. Traditions and modernity in veterinary medicine, Scientific Journal of the Faculty of Veterinary Medicine of University of Forestry, Sofia, 1, 1: 67-72. ISSN 2534-9333, e- ISSN 2534-9341.

16. Rabin, J. 1986. Pack tomatoes for higher profits - chlorinating packing shed wash water improves quality. American Vegetable Grower 34, 8, 12. 
17. Tasheva, Y., Petkov Y., Karadzhov S. 2010. Test of the action of electrochemically activated aqueous solutions (anolytes) on Candida albicans. Proceedings of the FVM, UF, Sofia "Traditions and contemporaneity in Veterinary Medicine", pp. 152-158. 